\title{
BEHAVIOURAL STUDIES ON TRIPLE BLENDED FOAM CONCRETE
}

\author{
G.V.V. Satyanarayana ${ }^{1}, P$. Gayathri $^{2}$ \\ ${ }^{1}$ Professor, Dept. of Civil Engineering, Gokaraju Rangaraju Institute of Engineering and Technology, Hyderabad, \\ India. \\ ${ }^{2}$ P.G.Scholar, Dept. of Civil Engineering, Gokaraju Rangaraju Institute of Engineering and Technology, Hyderabad, \\ India
}

\begin{abstract}
In recent days construction industry focuses on other than conventional concrete in infrastructural purposes like building etc., due to excess usage of cement, sand and other aggregates which leads depreciation of natural resources and effects on the environment. By utilization of lightweight bricks and foam concrete which reduces not only its self-weight but also improve resistance against heat and sound insulation and architectural features. The density of foam concrete varies from 300 to $1800 \mathrm{~kg} / \mathrm{m}^{3}$. Foam concrete composes of cement, water, fly ash and foaming agent without coarse aggregate. The function of foam is to create air bubbles in the cement-based slurry. The density of foam concrete depends on the quantity of foam added. The foam creates several pores with this effect; it has low thermal conductivity. As density of foam concrete is low at same time strength also low when compared to conventional concrete, so an attempt made to improve mechanical properties of foam concrete by adding admixtures like Silica fume and GGBS in different percentages. In these experimental studies, the workability and compressive strengths are mentioned
\end{abstract}

\section{INTRODUCTION}

Foam concrete is also known as aerated concrete without coarse aggregate with low density. Er.G.V.V.S.P.Anvesh and, Dr.G.V.V.Satyanarayana[1] reviewed the basic properties and advantages of foam concrete. In general, the mechanical properties of foam concrete will be low when compared to conventional concretes. Anju P Rajan \& Aneeta Anna Raju[2] concluded that the strength of foamed concrete varies with foam content. The foam creates an air void in cement-based slurries, by the usage of foam concrete become more slurry which increases filling ability. Mohamed Abdelrahman et al [3] were studied the microstructure of the foamed concrete to improve mechanical properties of foam concrete using Scanning electron microscopy (SEM). Hongyu Zhou and Adam L. Brooks[4] was performed and revealed the interaction mechanisms between fillers, aggregates, and the cement matrix to improve mechanical properties. The strength and other properties of foam concrete depend on the

\section{MATERIALS USED}

\subsection{Cement}

In this investigation, the ordinary Portland cement (OPC) of Grade 53 is used. The various properties and density of foam concrete. The density of foam concrete always depends on foam content. Daniel Hatungimana[5,7] concluded that mixtures having high foam content, Silica fume introduction resulted in superior compressive strength. Foam is generating separately with the help of foaming agents mixed with water. The cement paste or slurry collects around the foam bubbles, and the paste has enough strength to keep its form around the air voids. The agent is calculated based on the density of the foam. Shibi Varghese \&Ashik M Ashok [6,8] were tried partial replacement of binding material with silica-Fume which provides additional strength compared to foam concrete without silica fume along with synthetic foam agent. So in this experimental investigation examined or studied the improvement of mechanical properties with partial replacement of cement content by different mineral admixtures like Silica Fume and GGBS along with the synthetic foaming agent.

chemical composition of cement tested and tabulate in Table1 and Table2.

Table 1. PROPERTIES OF CEMENT

\begin{tabular}{|c|c|c|}
\hline Properties of concrete & Result & $\begin{array}{c}\text { Requirement } \\
\text { as per }\end{array}$ \\
\hline
\end{tabular}




\begin{tabular}{|c|c|c|}
\hline & & $\begin{array}{l}\text { IS:8112- } \\
\mathbf{1 9 8 9}\end{array}$ \\
\hline Specific gravity & 3.15 & $3.10-3.15$ \\
\hline Standard consistency & $31 \%$ & $30-35(\%)$ \\
\hline Initial setting time & $50 \mathrm{~min}$ & $\begin{array}{c}30 \text { minutes } \\
\text { (minimum) }\end{array}$ \\
\hline Final setting time & $178 \mathrm{~min}$ & $\begin{array}{c}600 \text { minutes } \\
\text { (maximum) }\end{array}$ \\
\hline $\begin{array}{c}\text { Compressivestrengthat } \\
\text { 28days }\end{array}$ & 58 \\
$\mathrm{~N} / \mathrm{mm}^{2}$ & $53 \mathrm{~N} / \mathrm{mm}^{2}$ \\
\hline
\end{tabular}

Table 2 .CHEMICAL COMPOSITION OF CEMENT

\begin{tabular}{|c|c|}
\hline Compound & $\begin{array}{c}\text { Chemical } \\
\text { composition (\%). }\end{array}$ \\
\hline Lime $(\mathrm{CaO})$ & 64.64 \\
\hline Silica $\left(\mathrm{SiO}_{2}\right)$ & 21.28 \\
\hline Alumina $\left(\mathrm{Al}_{2} \mathrm{O}_{3}\right)$ & 5.60 \\
\hline Iron oxide $\left(\mathrm{Fe}_{2} \mathrm{O}_{3}\right)$ & 3.36 \\
\hline Sulphar Trioxide $\left(\mathrm{SO}_{3}\right)$ & 2.14 \\
\hline Magnesia $(\mathrm{MgO})$ & 1.51 \\
\hline MnO & 0.10 \\
\hline $\mathrm{N} \mathrm{O}^{\mathrm{O}}$ & 0.51 \\
\hline Loss on ignition & 0.64 \\
\hline Insoluble residue & 1.23 \\
\hline
\end{tabular}

\subsection{Fly ash}

It is heterogeneous by-product material produced in the combustion process of coal used in power stations and industries. It is a fine grey coloured. In this investigation Class F fly ash is used. Fly ash collected from RMC unit. The fly ash is a very fine material; the particle size ranges in between 10to 100 micron.

Table 3.COMPOSITION OF FLY-ASH

\begin{tabular}{|c|c|}
\hline Compound & Chemical composition (\%) \\
\hline $\mathrm{SiO}_{2}$ & 55 \\
\hline $\mathrm{Al}_{2} \mathrm{O}_{3}$ & 26 \\
\hline $\mathrm{Fe}_{2} \mathrm{O}_{3}$ & 7 \\
\hline $\mathrm{CaO}$ & 9 \\
\hline $\mathrm{MgO}$ & 2 \\
\hline $\mathrm{SO}_{3}$ & 1 \\
\hline
\end{tabular}

\subsection{Silica fume}

Silica fume is also known as micro silica, and Silica fume is an ultrafine material with spherical particles less than 1 micron in diameter. The specific gravity of silica fume is generally ranging from 2.2 to 2.3. Silica Fume collected from RMC unit used in this investigation. Silica fume is very extreme fineness material due to this it has very effective pozzolonic material. By adding the silica fume to ordinary Portland cement, it improves its mechanical properties such as compressive, Flexural and Split tensile strength also reduces the permeability of concrete.

\subsection{GGBS (Ground Granulated Blast Furnace Slag)}

It is a by-product of iron and steel manufacturing .It will produces by fine rolling of slag coming from blast furnace. It increases the mechanical properties, durability and appearance of the concrete. By adding the GGBS in the mixture the concrete mixture provides fast setting and low heat hydration.

\subsection{Foaming agent}

We collected the material from CLC bricks making factory it is an synthetic foaming agent is used in this investigation which is suitable for ordinary Portland cement and greater workability. It is a Sodium Laurent Sulfate (Synthetic foaming agent). It is very light in weight; colorless does not possess any odour also nontoxic. The quantity of foam agent has to be used according to required density foam concrete. This synthetic foaming agent helps to reduce surface tension of liquid the agent is mixed with water in the ratio of 1:30. To generate foam we had used foam generator, which is connected to air compressor. Then the air compressor is started and we have to wait until the air pressure in the compressor reaches to $2 \mathrm{lbs}$. and then we have to open the valve of air compressor, which allows air to enter in to foam generator. In foam generator we have maintain constant pressure of $2 \mathrm{lbs}$., then after 5 minutes we can generate thick foam.

\section{METHODOLOGY}

In this experimental investigation, according to previous literature, various preliminary tested conducted for all raw materials. A mix designed is completed as per material properties and find out the proportions of foam concrete has been carried out. Once the mix design completed, trail mixes have made to check whether the target density was been achieved or not. If the target density has not attained some alterations has been made in water-cement ratio and foam content. Then cubes cast with and without admixtures for the required densities. Weights of moulds is noted down before and after casting. Then weights of cubes have been noted down to check whether target density achieved or not. After the cubes are de-moulded and kept in curing tank at ambient temperatures. After a sufficient period of curing, the specimens are tested for dry density and compressive strength if the cubes attained the target density. 


\section{MIX DESIGN}

In foam concrete mix design, the target density is a key factor to decide the mix proportions. Based on the past literature, target density is kept in mind to design a foam concrete mix as per material properties used in this experimental investigation.

\subsection{THE MIX DESIGN PROCEDURE AS FOLLOWS:}

In this investigation, cement content is calculated by assuming water/cement and fly ash/cement ratios. The main formula used to calculate the number of materials mentioned.

Target density $=$ cement content $(\mathrm{C})+$ water content $(\mathrm{W})$ + fly ash (F)

$1 \mathrm{~m}^{3}=\mathrm{V}($ foam $)+\frac{\mathrm{Wc}}{(\mathrm{Sc} \times \mathrm{Dw})}+\frac{\mathrm{Ww}}{(\mathrm{Sw} \times \mathrm{Dw})}+\frac{\mathrm{Ws}}{(\mathrm{Ss} \times \mathrm{Dw})}$

$\mathrm{W}_{\mathrm{C}}=$ Cement content

$\mathrm{W}_{\mathrm{W}}=$ Water content

$\mathrm{W}_{\mathrm{S}}=$ Sand content $\left(\mathrm{Kg} / \mathrm{m}^{3}\right)$

$\mathrm{S}_{\mathrm{C}}=$ Specific gravity of cement

$\mathrm{S}_{\mathrm{W}}=$ Specific gravity of water

$\mathrm{D}_{\mathrm{W}}=$ Density of water

\subsubsection{PROPORTION FOR THE DENSITY $\left(900 \mathrm{~kg} / \mathrm{m}^{3}\right):$}

Assumed target density $=900 \mathrm{~kg} / \mathrm{m}^{3}$

Assumed water cement ratio $=0.8$

Assumed sand cement ratio $=2$

$900 \mathrm{~kg} / \mathrm{m}^{3}=\mathrm{C}($ cement $)+2$ (fly ash $)+0.8$ (water)

Cement content $(\mathrm{C})=236.84 \mathrm{Kg} / \mathrm{m} 3$

Fly ash content $(\mathrm{F})=473.68 \mathrm{Kg} / \mathrm{m} 3$

Water content $(\mathrm{W})=189 \mathrm{Kg} / \mathrm{m} 3$

Volume of foam $\left(\mathrm{V}_{\mathrm{F}}\right)=1$

$\mathrm{V}_{\mathrm{F}=1}-\frac{236}{3.14 \times 1000}+\frac{473.68}{2.66 \times 1000}+\frac{189}{1 \times 1000}=0.6$

$\mathrm{V}_{\mathrm{F}}=1-\frac{236}{3.14 X 1000}+\frac{473.68}{2.66 \times 1000}+\frac{189}{1 X 1000}=0.7$

Table 4. AMOUNT OF REPLACEMENT OF CEMENT

\begin{tabular}{|c|c|c|}
\hline $\begin{array}{c}\text { Nomenclature } \\
\text { of Mix }\end{array}$ & $\begin{array}{c}\text { Silica fume(\%) } \\
\left(\mathbf{k g} / \mathbf{m}^{\mathbf{3}}\right)\end{array}$ & $\begin{array}{c}\text { GGBS( \%) } \\
\left(\mathbf{k g} / \mathbf{m}^{\mathbf{3}}\right)\end{array}$ \\
\hline M1 & 0 & 0 \\
\hline M2 & 2.5 & 27.5 \\
\hline M3 & 5 & 25 \\
\hline M4 & 7.5 & 22.5 \\
\hline
\end{tabular}

Table 5. MIX DESIGN - 1

(WITHOUT ANY REPLACEMENT) IN Kg/m $\mathrm{m}^{3}$

\begin{tabular}{|c|c|c|c|c|c|c|}
\hline D & cement & GGBS & $\begin{array}{c}\text { Fly- } \\
\text { ash }\end{array}$ & $\begin{array}{c}\text { Silica- } \\
\text { fume }\end{array}$ & water & $\mathbf{V}_{\mathbf{F}}$ \\
\hline 900 & 236 & 0 & 472 & 0 & 189 & 0.6 \\
\hline
\end{tabular}

Table 6 MIX DESIGN - 2

(WITH REPLACEMENT OF CEMENT WITH 2.5\% OF SILICA FUME AND 27.5\% GGBS) IN Kg/m $\mathrm{m}^{3}$

\begin{tabular}{|c|c|c|c|c|c|c|}
\hline D & cement & GGBS & $\begin{array}{c}\text { Fly- } \\
\text { ash }\end{array}$ & $\begin{array}{c}\text { Silica- } \\
\text { fume }\end{array}$ & water & $\mathbf{V}_{\mathbf{F}}$ \\
\hline 900 & 165 & 45.37 & 330 & 4.12 & 132 & 0.7 \\
\hline
\end{tabular}

Table 7 MIX DESIGN - 3

(WITH REPLACEMENT OF CEMENT WITH 5\% OF SILICA FUME AND 25\% GGBS) IN Kg/m ${ }^{3}$

\begin{tabular}{|c|c|c|c|c|c|c|}
\hline D & Cement & GGBS & $\begin{array}{c}\text { Fly- } \\
\text { ash }\end{array}$ & $\begin{array}{c}\text { Silica } \\
\text { fume }\end{array}$ & Water & $V_{F}$ \\
\hline 900 & 165 & 41.25 & 330 & 8.25 & 132 & 0.7 \\
\hline
\end{tabular}

Table 8 MIX DESIGN - 4

(WITH REPLACEMENT OF CEMENT WITH 7.5\% OF SILICA FUME AND $22.5 \%$ GGBS) IN Kg/m $\mathrm{m}^{3}$

\begin{tabular}{|c|c|c|c|c|c|c|}
\hline D & cement & GGBS & $\begin{array}{c}\text { Fly- } \\
\text { ash }\end{array}$ & $\begin{array}{c}\text { Silica- } \\
\text { fume }\end{array}$ & water & $V_{F}$ \\
\hline 900 & 165 & 37.13 & 330 & 12.37 & 132 & 0.7 \\
\hline
\end{tabular}

\section{EXPERIMENTAL INVESTIGATION}

Mix proportion: in this experimental investigation, we used density of $900 \mathrm{~kg} / \mathrm{m}^{3}$, we used cement, water, Fly ash foaming agent and replacing the amount of cement $30 \%$ with different material like silica fume and GGBS. The density calculation code is IS456-2000.

Table 9. PERCENTAGES OF ADMIXTURES

\begin{tabular}{|c|c|c|c|c|}
\hline Mix & $\begin{array}{l}\text { OPC } \\
\text { Cement } \\
\%\end{array}$ & $\begin{array}{l}\text { Fly } \\
\text { ash\% }\end{array}$ & $\begin{array}{l}\text { Silica } \\
\text { fume\% }\end{array}$ & GGBS\% \\
\hline M1 & 100 & 0 & 0 & 0 \\
\hline M2 & 0 & 70 & 2.5 & 27.5 \\
\hline M3 & 0 & 70 & 5 & 25 \\
\hline M4 & 0 & 70 & 7.5 & 22.5 \\
\hline
\end{tabular}

\subsection{CASTING AND DEMOULDING}

Weighing all the materials in the electronic meter. First cubes are cleaned well and apply oil to the inner surface of the cubes. Then fill the cubes with the concrete which is prepared no compaction is required. Then after the completion of $24 \mathrm{hrs}$, remove the blocks from the mould. The different mixes are made by changing the percentages of admixtures. After the completion of $24 \mathrm{hrs}$ moulds are demoulded and are cured with water. 


\subsection{WORKABILITY TEST}

It is the freshly mixed concrete which determines the ease and homogeneity with which it can be placed, mixed and transported easily from RMC plant to construction field.In this investigation to obtain workability of foam concrete Flow table test is done. Apparatus of flow table are, metal used for making of flow table is $1.5 \mathrm{~mm}$ thick and its dimensions are $750 \mathrm{~mm} \times 750 \mathrm{~mm}$, metal cone lower dia $=20 \mathrm{~cm}$, upper dia $=13 \mathrm{~cm}$ and height of cone $=20 \mathrm{~cm}$. It consist a handle to lift the flow table when we want to check flow of concrete in which coarse aggregate is used.

Table 10. WORKABILITY TEST

\begin{tabular}{|c|c|c|}
\hline DENSITY & MIX & $\begin{array}{c}\text { WORKABILITY } \\
(\mathbf{m m})\end{array}$ \\
\hline 900 & $\mathrm{MIX}-1$ & 430 \\
\hline 900 & $\mathrm{MIX}-2$ & 438 \\
\hline 900 & $\mathrm{MIX}-3$ & 435 \\
\hline 900 & $\mathrm{MIX}-4$ & 436 \\
\hline
\end{tabular}

\section{PLASTIC DENSITY}

In this investigation plastic density of cubes is calculated. To determine plastic density, we need to subtract the weight of mould filled with material $\left(\mathrm{W}_{2}\right)$ and the weight of an empty mould $\left(\mathrm{W}_{1}\right)$.

$\mathrm{W}_{1}=$ WEIGHT OF EMPTY MOULD

$\mathrm{W}_{2}=$ WEIGHT OF MOULD WITH CEMENT CONTENT

Table 11. PLASTIC DENSITY VALUES

\begin{tabular}{|l|c|c|c|c|}
\hline D & MIX & $\begin{array}{c}\mathbf{W}_{\mathbf{1}} \\
\left(\mathbf{k g} / \mathbf{m}^{\mathbf{3}}\right)\end{array}$ & $\begin{array}{c}\mathbf{W}_{\mathbf{2}} \\
\left(\mathbf{k g} / \mathbf{m}^{\mathbf{3}}\right)\end{array}$ & $\begin{array}{c}\text { PLASTIC } \\
\text { DENSITY } \\
\left.\mathbf{( k g}_{\mathbf{3}} \mathbf{m}^{\mathbf{}}\right)\end{array}$ \\
\hline 900 & MIX-1 & 9.33 & 12.949 & 3.619 \\
\hline 900 & MIX-2 & 9.627 & 13.683 & 4.056 \\
\hline 900 & MIX-3 & 9.526 & 13.312 & 3.786 \\
\hline 900 & MIX-4 & 9.211 & 12.976 & 3.765 \\
\hline
\end{tabular}

\section{DRY DENSITY}

It is find out the weight of the dry mould after 7, 14 and 28days of curing period of time.

Table 12. DRY DENSITY

\begin{tabular}{|c|c|c|c|}
\hline Density & Mix & $\begin{array}{c}\text { Cube } \\
\text { number }\end{array}$ & Dry density \\
\hline 900 & 1 & 1 & 3.102 \\
\hline 900 & 2 & 1 & 3.411 \\
\hline 900 & 3 & 1 & 3.308 \\
\hline 900 & 4 & 1 & 3.169 \\
\hline
\end{tabular}

\section{COMPRESSIVE STRENGTH}

The cubes of sizes $150 \mathrm{~mm} \times 150 \mathrm{~mm} \times 150 \mathrm{~mm}$ are used to test the compressive strength of the concrete. Cubes are prepared for 14 and 28 days.

Table 13. COMPRESSIVE STRENGTH (M2)

\begin{tabular}{|c|c|c|c|c|c|}
\hline S.NO & $\begin{array}{c}\text { DENSITY } \\
\text { OF FOAM } \\
\text { CONCRETE }\end{array}$ & $\begin{array}{c}\text { SPECIM } \\
\text { EN }\end{array}$ & \multicolumn{3}{|c|}{$\begin{array}{c}\text { COMPRESSIVE } \\
\text { STRENGTH } \\
\text { (N/mm }\end{array}$} \\
\cline { 4 - 6 } & & & $\mathbf{7 ~ D}$ & $\mathbf{1 4} \mathbf{D}$ & $\begin{array}{c}\mathbf{2 8} \\
\mathbf{D}\end{array}$ \\
\hline 1 & \multirow{2}{*}{900} & 1 & 1.05 & 3.56 & 4.2 \\
\cline { 3 - 6 } & & 2 & 1.00 & 3.42 & 4.5 \\
\cline { 3 - 6 } & & 3 & 1.00 & 3.56 & 4.5 \\
\cline { 3 - 6 } & & Average & 1.02 & 3.51 & 4.4 \\
\hline
\end{tabular}

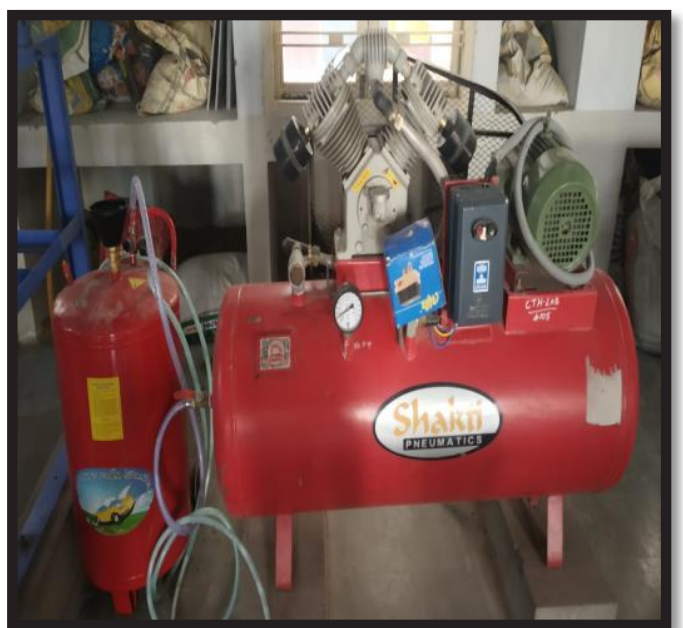

FIG-1 FOAM GENERATOR MACHINE

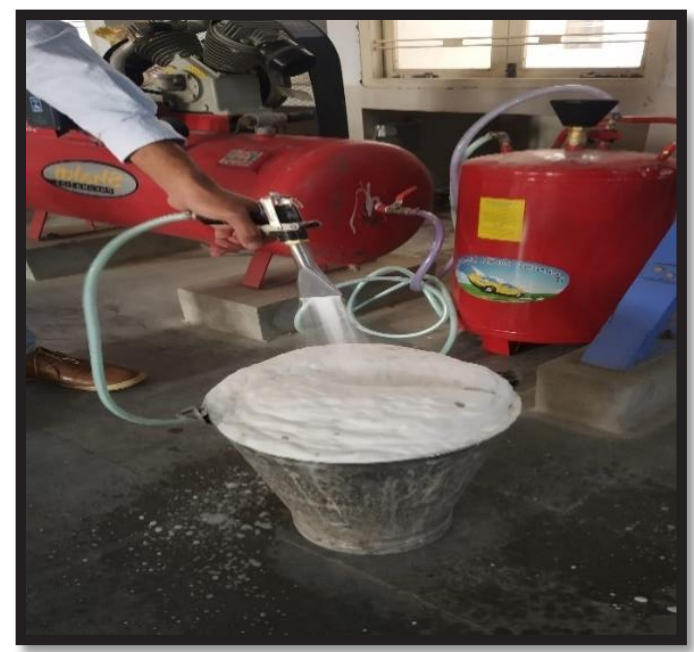

FIG-2 GENERATING FOAM FROM FOAM GENERATOR 


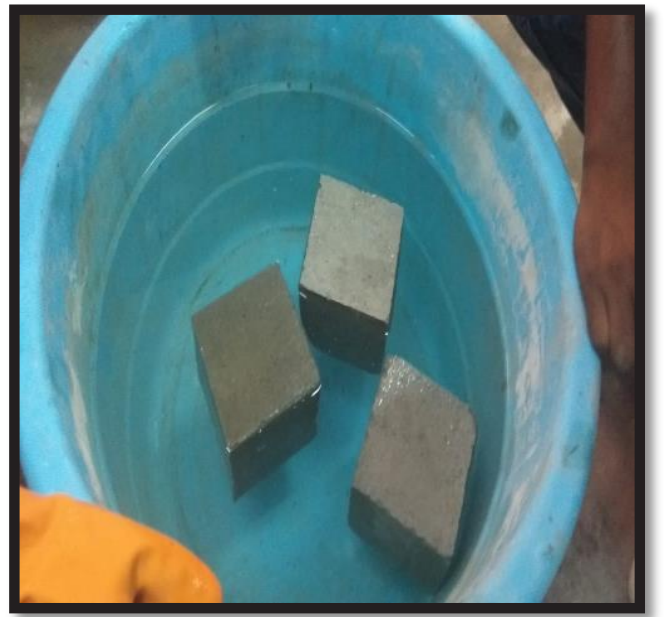

FIG-3 CUBES WHICH ARE FLOATING IN WATFR

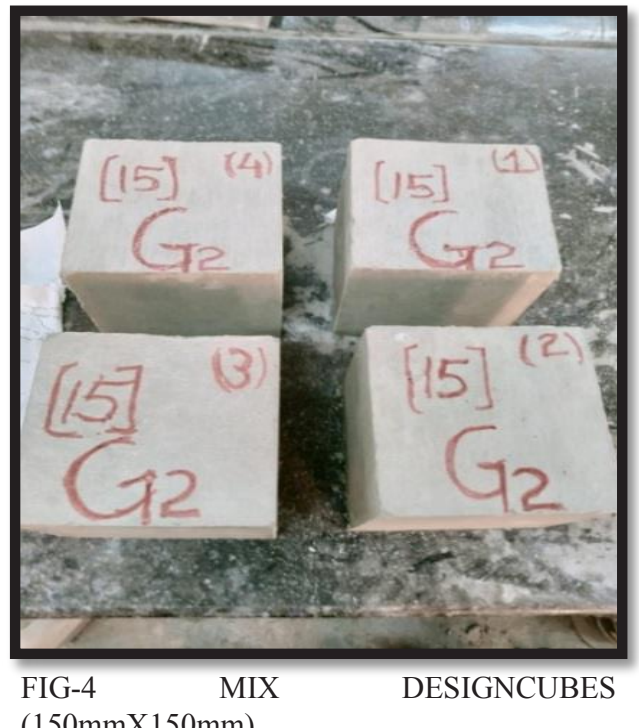

\section{CONCLUSION}

Workability of blended foam concretes are marginally increased when compared to conventional foam concrete. The maximum workability achieved in trail mix 2 .

a. The maximum plastic dry density achieved in trail mix 2, as workability also increased in that mix only.

b. As well as the maximum dry density also achieved in trail mix 2

c. The compressive strength also attained goo performance with available previous literature.

d. The workability, plastic, dry densities are improved in blended foam concretes due to admixtures.

e. As Silica fume content increases the workability decreased.

\section{REFERENCES}

1. G.V.V.S.P.Anvesh, G.V.V.Satyanarayana "A Review on Generation and Development of Foam Concrete, JETIR volume 7, issue 4 (2020)
2. Anju P Rajan\&Aneeta Anna Raju, "Experimental study on the strength of foamed concrete by varying foam content". (2019)

3. Mohamed AbdElraman, Mohamed E.EI Madawy, Sang-Yeop Chug, PawelSikora and Dietmar Stephan, "Preparation and Characterization of Ultra-lightweight Foamed Concrete Incorporating Lightweight Aggregates" (2019)

4. Hongyu Zhou, Adam L. Brooks "Thermal and Mechanical properties of lightweight structural concrete containing lightweight aggregates and flyash cenospheres." (2018)

5. Daniel Hatungimana, " Effect of fly ash and silica fume on hardened properties of foam concrete" (2018)

6. Shibi Varghese \&Ashik M Ashok, "A study on properties of foamed concrete with natural and synthetic". (2017)

7. Tummala Suresh Kumar, Kosaraju Satyanarayana, Materials Today: Proceeding, 26 (2), 3228-3233, (2020)

8. Maheshkumarh.Thakrele, "Experimental Study On FoamConcrete" (2014) 